\title{
The Effect of Extract of Oak Gall for Vaginal Tightening and Rejuvenation in Women with Vaginal Relaxation
}

\author{
Nahid Lorzadeh*, Friba Sepavand, Maryam Soleimaninezhad, Nastaran Kazemirad \\ Department of Obstetrics and Gynecology, Faculty of Medicine, Lorestan University of Medical Sciences, Khorrmabad, Iran \\ Email: *nahid442000@yahoo.com
}

How to cite this paper: Lorzadeh, N., Sepavand, F., Soleimaninezhad, M. and Kazemirad, N. (2016) The Effect of Extract of Oak Gall for Vaginal Tightening and Rejuvenation in Women with Vaginal Relaxation. Open Journal of Obstetrics and Gynecology, 6, 879-887.

http://dx.doi.org/10.4236/ojog.2016.613106

Received: May 18, 2016

Accepted: December 23, 2016

Published: December 26, 2016

Copyright $\odot 2016$ by authors and Scientific Research Publishing Inc. This work is licensed under the Creative Commons Attribution International License (CC BY 4.0).

http://creativecommons.org/licenses/by/4.0/

\section{Abstract}

Background and Objectives: The Quercus (oak) fruit and especially the internal layer of the fruit (jaft) is rich in tannin (polyphenolic compound) and due to its astringent effects on the smooth muscles, we decided to evaluate this effect of extract of Oak Gall for vaginal tightening and rejuvenation in women with vaginal relaxation. Methods: This double blind clinical trial was performed on women with vaginal relaxation at Asali Hospital in Khorramabad from May to October 2012 and was candidate for colporrhaphy due to different types of pelvic organ prolapse. Sampling method was done on nonprobability basis according to the number of patients referred to clinic. Using blocked random allocation method, the participants were divided into 4 groups of 30 patients (three intervention group and one control group) who were age-matched. Then, an extract of Oak Gall in specified concentrations (10 - 15 and 20 grams in $1.5 \%, 2 \%$ and $2.5 \%$ jells) were administered to each intervention group. Finally, the obtained data were analyzed with Chi-square, Pearson, Fisher's exact test and ANOVA using SPSS software version 19. Results: A total of 120 patients entered into the study with mean age of $36 \pm 5.4$ years. The evaluation of mean scores showed that sense of sexual satisfaction and orgasm, sense of vaginal tightness during intercourse, sense of vaginal lubrication and loss of vaginal dryness was significantly improved in patients in intervention group. Also other parameters including urinary incontinence, sense of vaginal mass exit, lack of orgasm, sense of air outflow during intercourse, sense of calmness after sex and loss of libido were significantly reduced in the group of patients who received jell $2.5 \%$ compared to other groups $(\mathrm{P}<0.0001)$. Conclusion: Our findings show that using topical jell of Oak Gall not only is associated with contracting effects, but also improves vaginal lubrication and reduces its dryness. Regarding the lack of previous studies in this field and considering some limitations of this study, we suggest that Oak Gall to be used for management of women with vaginal relaxation. 


\section{Keywords}

Extract of Oak Gall, Vaginal Tightening and Rejuvenation, Vaginal Relaxation

\section{Introduction}

Sexual desire is a God given gift that requires proper attention like other blessings and natural instincts such as sleep, hunger, thirst etc. and also requires proper care and hygiene as well as appropriate treatment if any problem or disease occurs [1] [2]. Because most of the people in our country are very embarrassed for talking about sexual issues, so most of the marriages are associated with unawareness of the couples about sexual behavior and after a while, they may encounter a lot of problems in their sexual relationships [3] [4] [5].

Sexual satisfaction is affected by different factors including occupational stress, conflicts in couple relationships, educational and cultural level, economic problems, moral and sexual compatibilities, mental disorders and physical diseases of both parties [6]. Relaxation of pelvic floor muscles is one of the physical problems [7] that leads to pelvic organ prolapse, dysfunction of pelvic organs, dyspareunia, low back pain, sexual dysfunction and lack of sexual satisfaction in couples [8].

Although the pelvic organ prolapse and relaxation of pelvic floor muscles have been recognized as factors that affect sexual satisfaction [9], and one third of women with pelvic organ prolapse suffer from sexual dysfunction and lack of sexual satisfaction [10], but the study by Weber et al. did not show significant correlation between sexual satisfaction and pelvic organ prolapse [11].

There are several therapeutic approaches for management of pelvic organ prolapsed including surgical and nonsurgical methods. Using pessary, Kogel exercises, physiotherapy and hormone therapy are nonsurgical methods and posterior and anterior colporrhaphy are surgical methods [12]. Some authors such as Barder et al. have shown that colporrhaphy can improve sexual function and sexual satisfaction; while others such as Roger et al. have indicated that sexual satisfaction may be decreased in participants 3 - 6 months after surgery [9] [13].

Herbal remedies have long been used to treat various diseases. The oak is one of the plants with many therapeutic applications. The oak that is used in this study is from the species of Quercusinfectoria and Quercusbrantii which are grown in Lorestan province (Khorramabad and Doroud cities). This oak has grey-green leaves with fuzzy branches with oval fruit weighting 15 - 20 grams like a capsule locatedin a cup. This species have long duration of life that Food and Agriculture Organization (FAO) has estimated their life as 700 to 1000 years [14].

Iranian oak fruit has composed of two parts: the cup and the capsule. The capsule has three parts: external layer which encircles the capsule and shares $7 \%$ of fruit weight. Jaft (tannin) which is an internal thin layer wrapped around the brain (second shell). This part shares $3 \%$ of dried fruit weight; it means that from 1 kilogram of dried oak fruit, 30 
grams of dried jaft (tannin) can be retrieved. The last part is the brain of oak fruit. The brain is soft as long as the fruit is not dried; however as the time passes, due to evaporation of internal water, the brain weight is diminished; because $40 \%$ of the weight of raw fruit is due to water and minerals. The fruit is a nut enclosed in a cup called the cupule. Chemical compounds such asshikimic acid, methyl salicylate, terpenoid compounds and especially tannins can be found in these plants. The oak shell is a good antidote for poisonings caused by alkaloids and minerals [14] and the internal layer of oak fruit that is called jaft has copious amount of tannins. The therapeutic effects of tannins are astringent, anti-diarrhea, styptic, relieves stomach bleeding and bleeding between menstrual cycles, relieves bloody phlegms, helps tissue edema andreduces albuminuria caused by renal insufficiencies.

In topical application, due to astringent effects, it is used for constriction of vagina and anus, relievesvaginal discharge, oozing eczema, hyperhidrosis, crack and fissures of the nipple, burns, hemorrhoids, anal fissures, nasal and laryngeal coryza and denatures toxic compounds of antihistamines and also may be useful for recently healed wounds by creating a protective layer on them [15]. Moliawan et al. in a study published on 2006 declared that methanol extract of Quercuslusitanica has a significant inhibitory effect on replication of Dengue virus type-2 [16]. The effects of an herbal compound composed of internal layer of oak and lemon balm in treatment of minor aphthous ulcers in oral mucosa has been associated with successful treatment of this disease [17]. Also, a study on Quercusaucheri showed that oak gallsacts as an astringent antiseptic and coagulating agent. The sodden is also used for acute diarrhea, inflammation, burns and wounds [18].

Haidari et al. with regard to different therapeutic effects of tannins including inhibition of pathogenic growth, styptic and astringent properties, applied the tannin powder within the Quercusinfectoria for healing of skin wound in rats [19]. Another study was done by Umachigi et al. on 2008 focusing on the features of wound healing in rats after application of ethanol extract of galls and they found that wound healing is accelerated [20].

Regarding the astringent effects of jaft tannins and its effects on smooth muscles, we decided to evaluate this effect in order to contract vaginal smooth muscles in women with vaginal relaxation.

\section{Methods}

This study was a double-blind clinical trial registered at www.irct.ir website (code number: $137704071842 \mathrm{~N} 2$ ). All marriedwomen with vaginal relaxation who referred to gynecology clinic at Asali Hospital in Khorramabad from May to October 2012 and were candidate for colporrhaphy due to different types of pelvic organ prolapse were considered for the study. Among them, 120 women who had child, at educational level of guidance school or higher, without history of pelvic or breast surgery, no drug abuse, no chronic disease (diabetes, hypertension, ischemic heart disease) in themselves and their spouse, and no sexual problems (premature ejaculation and impotence) in their 
spouse and with no urogenital infections were entered in the study.

Sampling method was done on nonprobability basis according to the number of patients referred to the clinic. All women were examined in lithotomy position in order to determine prolapse grade and were graded based on Pelvic Organ Prolapse Quantification System (POP-Q). Using blocked random allocation method, the participants were divided into 4 groups of 30 patients (three intervention group and one control group) who were age-matched. After explaining the study objectives for participants and obtaining written informed consent for participation in the study, the questionnaire number 1 (demographic data) and questionnaire number 2 (sexual satisfaction) were filled by them. Then, an extract of internal layer of Quercus in specified concentrations (10 - 15 and 20 grams in 1.5\%, 2\% and 2.5\% jells) were administered to each intervention group. For control group, just the basic jell (methyl paraffin 2\%, acetic acid, deionized water and glycerin) without oak extract was administered. The participants were asked to use different concentrations of this intravaginal extract 3 days after the end of menstruation, 5 minutes before sexual contact. Instructions for intercourse were also delivered to them. On the day after intercourse, all women in 4 groups were evaluated in terms of sexual satisfaction and adverse events using Pelvic Organ Prolapse/Urinary Incontinence Sexual Function Questionnaire (PISQ). After determining the percentage, the acquired scores of the questionnaires were classified into 5 classes of completely satisfied (81 - 100), fairly satisfied (61 - 80), no idea (41 - 60), fairly unsatisfied (21 - 40) and completely unsatisfied $(0-20)$. The validity of instrument was evaluated by content validity and the reliability was evaluated by Cronbach's alpha (sexual satisfaction questionnaire Cronbach 89\%).For determining reliability of physical examination and grade of pelvic organ prolapse, the correlation coefficient (Spearman $r=96 \%$ ) was applied. Finally, the obtained data were analyzed with Chi-square, Pearson, Fisher's exact test and ANOVA using SPSS software version 19.

\section{Results}

This study was performed on 120 patients with mean age of $36 \pm 5.4$ years. All participants had at least one vaginal delivery and 42 women (35\%) had at least one cesarean section. The most common type of prolapse was perineal relaxation that was noted in 78 patients (65\%); while 42 women (35\%) had cystocele (bladder prolapse). The mean sexual satisfaction in the study subjects after intervention compared to before intervention showed that it was significantly greater in the group receiving oak extract jell 2.5\% (Table 1).

The differences in the frequency of orgasms was statistically significant among the groups and the highest amount of orgasm was noted in the group receiving oak extract jell 2.5\%; as women who always or often experienced orgasm was about $60 \%$ while $60 \%$ of women receiving placebo rarely or never experienced orgasm $(\mathrm{P}<0.001)$ (Figure 1).

In case of sexual problems in women, before and after using oak extract jell, these findings were observed:

The sense of vaginal tightness during intercourse in women receiving oak extract jell 
Table 1. Frequency of sexual satisfaction in the study subjects after intervention.

\begin{tabular}{cccccc}
\hline Sexual satisfaction & $\begin{array}{c}\text { Unsatisfied } \\
\text { Number } \\
\text { Study groups }\end{array}$ & $\begin{array}{c}\text { Fairly } \\
\text { unsatisfied } \\
\text { Number } \\
\text { (percentage) }\end{array}$ & $\begin{array}{c}\text { No idea } \\
\text { Number } \\
\text { (percentage) }\end{array}$ & $\begin{array}{c}\text { Fairly } \\
\text { satisfied } \\
\text { Number } \\
\text { (percentage) }\end{array}$ & $\begin{array}{c}\text { Completely } \\
\text { satisfied } \\
\text { Number } \\
\text { (percentage) }\end{array}$ \\
\hline Jell 2.5\% & $2(6.7)$ & $5(16.7)$ & $4(13.3)$ & $16(53.3)$ & $3(10)$ \\
Jell 2\% & $3(10)$ & $12(40)$ & $7(23.3)$ & $8(26.7)$ & $0(0)$ \\
Jell 1.5\% & $3(10)$ & $13(43.3)$ & $8(26.7)$ & $6(20)$ & $0(0)$ \\
Placebo & $3(10)$ & $14(46.7)$ & $8(26.7)$ & $5(16.7)$ & $0(0)$ \\
\hline
\end{tabular}

Type of statistical test: Fisher's exact test $\mathrm{P}$ value $=0021 ; \mathrm{X}^{2}=23.95 .{ }^{*}$ After intervention, the level of sexual satisfaction in women receiving jell $2.5 \%$ was significantly higher than other groups.

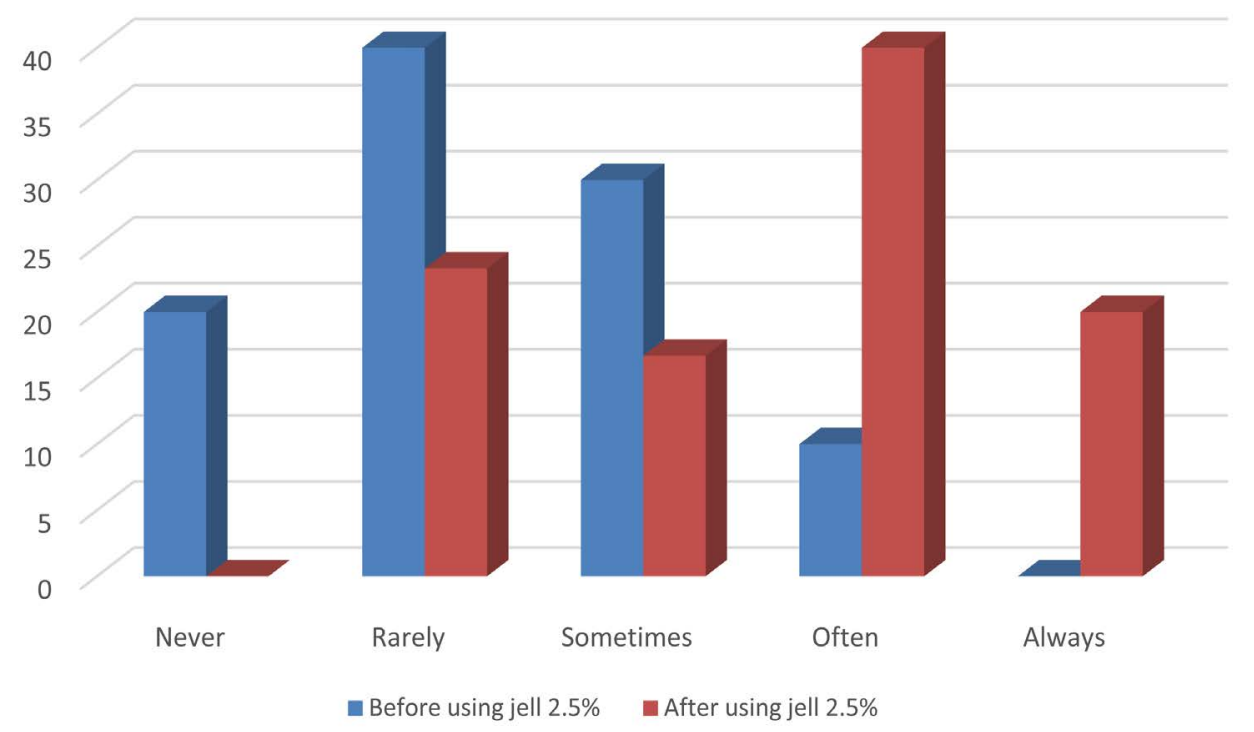

Figure 1. The differences in the frequency of orgasms was statistically significant among the groups and the highest amount of orgasm was noted in the group receiving oak extract jell $2.5 \%$.

$2.5 \%$ was significantly different compared to women receiving jell $2 \%$ and $1.5 \%$; as 28 out of 30 women in this group (93\%) reported the sense of vaginal tightness immediately after receiving jell $2.5 \%$ while this amount in groups receiving jell $2 \%$ and $1.5 \%$ was $33 \%$ and $6.7 \%$ respectively (Table 2 ).

Sense of vaginal dryness was another common finding that after using the mentioned amount of oak extract jell, the maximal efficacy was noted in the group receiving jell $2.5 \%$ (26 out of $30 ; 86 \%$ ) while this amount in other groups was $43 \%$ and $33 \%$ (Table 3).

The other parameters including urinary incontinence, sense of vaginal mass exit, lack of orgasm, sense of air outflow during intercourse, sense of calmness after sex and loss of libido were significantly reduced in the group of patients who received jell $2.5 \%$ compared to other groups $(\mathrm{P}<0.0001)$ (Table 4). 
Table 2. Frequency of the sense of vaginal tightness during intercourse in the study subjects after intervention.

\begin{tabular}{ccccc}
\hline $\begin{array}{c}\text { Sense of vaginal tightness during } \\
\text { intercourse }\end{array}$ & $\begin{array}{c}\text { No } \\
\text { Number } \\
\text { (percentage) }\end{array}$ & $\begin{array}{c}\text { Yes } \\
\text { Number } \\
\text { (percentage) }\end{array}$ & $\begin{array}{c}\text { Total } \\
\text { Number } \\
\text { (percentage) }\end{array}$ & P-Value \\
\hline Study groups & $2(6.7)$ & $28(93.3)$ & $30(100)$ & \\
Jell 2.5\% & $20(66.7)$ & $10(33.3)$ & $30(100)$ & $<0.0001$ \\
Jell 2\% & $28(93.3)$ & $2(6.7)$ & $30(100)$ & \\
Jell 1.5\% & $28(93.3)$ & $2(6.7)$ & $30(100)$ & \\
\hline Placebo & & &
\end{tabular}

Table 3. Frequency of the sense of vaginal dryness during intercourse in the study subjects after intervention.

\begin{tabular}{ccccc}
\hline Vaginal dryness during intercourse & $\begin{array}{c}\text { Yes } \\
\text { Number } \\
\text { (percentage) }\end{array}$ & $\begin{array}{c}\text { No } \\
\text { Number } \\
\text { (percentage) }\end{array}$ & $\begin{array}{c}\text { Total } \\
\text { Number } \\
\text { (percentage) }\end{array}$ & P-Value \\
\hline Jell 2.5\% & $4(26.7)$ & $26(86.7)$ & $30(100)$ & \\
Jell 2\% & $17(56.7)$ & $13(43.3)$ & $30(100)$ & $<0.0001$ \\
Jell 1.5\% & $20(66.7)$ & $10(33.3)$ & $30(100)$ & \\
Placebo & $20(66.7)$ & $10(33.3)$ & $30(100)$ & \\
\hline
\end{tabular}

Type of statistical test: Chi-square.

Table 4. Frequency of the efficacy of jell $2.5 \%$ in urinary incontinence, sense of vaginal mass exit, lack of orgasm, sense of air outflow during intercourse, sense of calmness after sex and loss of libido before and after intervention $(\mathrm{P}<0.0001)$.

\begin{tabular}{|c|c|c|c|c|c|c|}
\hline \multirow[b]{2}{*}{$\begin{array}{l}\text { Time-frequency } \\
\text { Sexual Problems }\end{array}$} & \multicolumn{2}{|c|}{ Before Intervention } & \multicolumn{2}{|c|}{ After the intervention } & \multirow[b]{2}{*}{ Total } & \multirow[b]{2}{*}{ P-Value } \\
\hline & $\begin{array}{c}\text { There } \\
\text { Number } \\
\text { (percentage) }\end{array}$ & $\begin{array}{c}\text { Do not have } \\
\text { Number } \\
\text { (percentage) }\end{array}$ & $\begin{array}{c}\text { There } \\
\text { Number } \\
\text { (percentage) }\end{array}$ & $\begin{array}{l}\text { Do not have } \\
\text { Number } \\
\text { (percentage) }\end{array}$ & & \\
\hline $\begin{array}{c}\text { Feel the air out during } \\
\text { intercourse }\end{array}$ & $29(96.7)$ & $1(3.3)$ & $5(16.7)$ & $25(83.3)$ & $30(100)$ & \\
\hline $\begin{array}{l}\text { Inability to achieve } \\
\text { orgasm }\end{array}$ & $24(80)$ & $6(20)$ & $7(23.3)$ & $23(76.7)$ & $30(100)$ & \\
\hline $\begin{array}{l}\text { Feeling out of the } \\
\text { vagina. }\end{array}$ & $22(73.3)$ & $8(26.7)$ & $7(23.3)$ & $23(76.7)$ & $30(100)$ & $<0.0001$ \\
\hline $\begin{array}{l}\text { Urinary incontinence } \\
\text { during orgasm }\end{array}$ & $28(93.3)$ & $2(6.7)$ & $2(6.7)$ & $28(93.3)$ & $30(100)$ & \\
\hline $\begin{array}{c}\text { Lack of relaxation } \\
\text { after a close }\end{array}$ & $30(100)$ & $0(0)$ & $10(33.3)$ & $20(66.7)$ & $30(100)$ & \\
\hline
\end{tabular}


No adverse event was observed following the use of oak extract jell in all study groups.

\section{Discussion and Conclusions}

The findings of this study showed that after using the oak extract jell $2.5 \%$, the sexual satisfaction and orgasm, sense of vaginal tightness during intercourse, sense of vaginal lubrication and loss of vaginal dryness was significantly higher than other study groups $(\mathrm{P}<0.001)$.

The studies show that when oak extract is applied topically, not only the tightening effects are appeared, but also the antioxidant effects on vaginal wall make the elasticity strength to be returned which had been caused by hormonal changes and vaginal delivery.

On the other hand, the natural antimicrobial effects of oak extract helps to prevent infection. In elderly women, the thinning of vaginal layers causes dyspareunia, vaginal dryness, redness and increased fungal and bacterial infections. The anti-inflammatory effects of oak extract jell can relieve the mentioned problems and help healing of damaged external tissue [17]. The effect of internal layer of oak and lemon balm has been studied in treatment of minor aphthous ulcers in oral mucosa and has been associated with successful treatment of this disease [20]. In a study on Quercusaucheri, it has been shown that oak galls act as an astringent, antiseptic and styptic agent.

Besides, the studies show that oak extract has natural antimicrobial effects that help reduce the infections caused by fungi, yeasts and bacteria which are main causes of itching and unpleasant odor of irritated vagina. Regarding the different therapeutic effects of tannins such as prevention of pathogenic growth and astringent and styptic effects, Haidari et al. used the tannin powder in the galls of Quercusinfectoria for healing of skin wounds [19]. Also, oak extract jell can relive vaginal dryness and lubricate the vagina that both effects improve sexual problems in women.

Using the oak extract jell was not associated with any adverse event, so can be used whenever it is required. The best application method is to be used twice daily (morning and evening) preferably on external area of the vagina. If the jell to be used 5 minutes before sexual contact, can also be considered as a natural lubricating agent.

The contracting effects of oak extract on the smooth muscles of the vagina are sensed immediately after applying; however, most of the women report that maximal effects are sensed after 10 - 15 minutes. Regarding the lack of previous studies in this topic and considering the significant improvement of symptoms in participants after using oak extract jell $2.5 \%$ and in spite of some limitations of the study such as inappropriate use of the extract, no further referring to clinic, moral excuse in responding questions and short duration of evaluation, we suggest that oak extract to be used in women as an appropriate treatment for sexual dysfunction.

\section{Acknowledgements}

We appreciate the members of Razi Research Center of Medicinal Plants of Lorestan 
University of Medical Sciences who hearty helped us for conducting this research.

\section{References}

[1] Owhadi, B. (2003) Human Sexuality. 3rd Edition, Attorpat Publication, Tehran, 85.

[2] Shokrollahi, P. (1996) Prevalence and Individual Risk Factors of Inadequacies of Sexual Response in Married Women Referred to Health Centers of the Tehran University of Medical Sciences. MSc of Midwifery Thesis, Tehran University of Medical Sciences, Tehran.

[3] Mahyar, A. and Noohi, S. (2003) Practical Guide to Treat Sexual Dysfunction. Moein Publication, Tehran, 7-8.

[4] Saki, K. and Bahrainian, S.A.H. (1999) Sexual Dysfunction in a Group of Iranian Population. Iranian Journal of Endocrinology and Metabolism, 1, 295.

[5] Hashemifard, A.A. (1992) Problems and Sexual Dysfunction in Men and Women. Chehr Publication, Tehran, 47.

[6] Pourafkari, N. (2000) Psychiatry of Behavioral Sciences-Clinical Psychiatry. Shahrab Publications, Tehran, 62 .

[7] Okonkwo, J.E., Obionu, C.O. and Obiechina, N.J. (2001) Factors Contributing to Urinary Incontinence and Pelvic Prolapse in Nigeria. International Journal of Gynecology \& Obstetrics, 74, 301-303. https://doi.org/10.1016/S0020-7292(01)00378-2

[8] Artibani, W., Stuart, L., Stanton, D. and Kumar, R. (2002) Pelvic Floor Reconstruction. Urology, 42, 1-11. https://doi.org/10.1016/s0302-2838(02)00036-2

[9] Barder, M., Visco, A. and Wyman, J. (2002) Sexual Function in Women with Urinary Incontinence and Pelvic Organ Prolapse. Obstetrics \& Gynecology, 99, 281-289.

[10] McLennan, A.H. (2000) The Prevalence of Pelvic Floor Disor-Ders and Their Relationship to Gender, Age, Parity and Mode of Delivery. British Journal of Obstetrics and Gynaecology, 107, 1460-1470. https://doi.org/10.1111/j.1471-0528.2000.tb11669.x

[11] Weber, A., Walters, M. and Piedmonte, M. (2000) Sexual Function and Vaginal Anatomy in Women Before and After Surgery for Pelvic Organ Prolapse and Urinary Incontinence. American Journal of Obstetrics \& Gynecology, 182, 1610-1615. https://doi.org/10.1067/mob.2000.107436

[12] Olsen, A., Smith, V.J., Bergstorm, J.O., Colling, J.C. and Clark, A.. (1997) Epidemiology of Surgically Managed Pelvic Organ Prolapse and Urinary Incontinence. Obstetrics \& Gynecology, 89, 501-506. https://doi.org/10.1016/S0029-7844(97)00058-6

[13] Rogers, R.G., Kammerer-Doak, D., Darrow, A., Mur-Ray, K., Olsen, A., Barber, M. and Qualls, C. (2004) Sexual Function after Surgery for Stress Urinary Incontinence and/or Pelvic Organ Prolapse: A Multicenter Prospective Study. American Journal of Obstetrics \& Gynecology, 191, 206-210. https://doi.org/10.1016/j.ajog.2004.03.087

[14] Khosravi, A.D. and Behzadi, A. (2006) Evaluation of the Antibacterial Activity of the Seed Hull of Quercus Brantii on Some Gram Negative Bacteria. Pakistan Journal of Medical Sciences, 22, 429-432.

[15] Motevaselian, M. and Farahi, F. (1979) Measurement of Extractive Materiales of Quercus infectoria for Foodstuff and Medicinal Value of It. Doctoral Thesis, Medical Faculty, Tehran University, Tehran.

[16] Muliawan, S.Y., Shamala Devi, L.S.K., Hashim, O. and Yusof, R. (2006) Inhibitory Potential of Quercus lusitanica Extract on Dengue Virus Type 2 Replication. Southeast Asian Journal of Tropical Medicine and Public Health, 37, 132-135.

[17] Jahanshahi, G.H., Moattar, F. and Soltani, M.R. (2004) Evaluation of a Herbal Medicine in 
the Treatment of Recurrent Aphthous Ulcer. Beheshti Univ. Dent. J, 22, 19-25.

[18] Sakar, M.K., Şhretoğlu, D., Zalp, M., Ekizoğlu, M., Placente, S. and Pizza, C. (2005) Polyphenolic Compounds and Antimicrobial Activity of Quercus aucheri Leaves. Turkish Journal of Chemistry, 29, 555-559.

[19] Haidari, R., Siami, A., Pakbaz, M. and Aghazadeh, M. (2005) Measurement of Tannin in Four Genotype of Quercus infectoria Olive and Application of Their Gall Powder in Treatment of Wound. J Aro. Med Pla Res. Iran, 21, 433-443.

[20] Umachigi, S.P., Jayaveera, K.N., Ashok Kumar, C.K., Kumar, G.S., Vrushabendraswamy, B.M. and Kishore Kumar, D.V. (2008) Studies on Wound Healing Properties of QuercusInfectoria. Tropical Journal of Pharmaceutical Research, 7, 913-919.

https://doi.org/10.4314/tjpr.v7i1.14677

Submit or recommend next manuscript to SCIRP and we will provide best service for you:

Accepting pre-submission inquiries through Email, Facebook, LinkedIn, Twitter, etc. A wide selection of journals (inclusive of 9 subjects, more than 200 journals)

Providing 24-hour high-quality service

User-friendly online submission system

Fair and swift peer-review system

Efficient typesetting and proofreading procedure

Display of the result of downloads and visits, as well as the number of cited articles

Maximum dissemination of your research work

Submit your manuscript at: http://papersubmission.scirp.org/

Or contact ojog@scirp.org 